\title{
PENDEKATAN RAMAH ANAK DALAM MENINGKATKAN MOTIVASI BELAJAR SISWA PADA MASA PANDEMI COVID-19 DI SDN 1 KILANG KABUPATEN LOMBOK TIMUR
}

\author{
MUHAMAD SUHARDI., HAROMAIN., WIDA SAFITRI \\ Universitas Pendidikan Mandalika Mataram \\ Email : ardhysmart7@gmail.com
}

\begin{abstract}
ABSTRAK
Tujuan penelitian dengan menggunakan pendekatan kualitatif dengan rancangan studi kasus diharapkan melalui pendekatan ramah anak siswa mampu meningkatkan motivasi belajar pada masa pandemic covid-19. Pendekatan ramah anak dalam pembelajaran masa pandemic covid-19 yang dilaksanakan melalui pembelajaran dalam jaringan (daring) ramah anak dan pembelajaran luar jaringan (luring) ramah anak. Data yang diambil dalam penelitian ini merupakan data hasil wawancara, observasi dan dokumentasi. Dalam pelaksanaan pendekatan ramah anak pada proses pembelajaran daring dan luring diperoleh hasil yang sesuai dengan apa yang diharapkan meskipun masih ada kendala dalam pelaksanaanya. Hal ini terlihat pada hasil wawancara yang dilakukan peneliti, bahwa ada suasana positif yang terjadi ketika pembelajaran dilaksanakan. Dimana guru dan siswa sangat antusias bahkan semangat dalam proses pelaksanaanya. Tentunya dalam proses pendekatan pembelajarannya guru dan siswa selalu menerapkan budaya $5 \mathrm{~S}$ yaitu budaya senyum, salam, sapa, santun dan sabar. Dengan demikian dapat dikemukakan bahwa pendekatan ramah anak dengan menggunakan pendekatan kualitatif dan rancangan studi kasus mampu meningkatkan motivasi belajar siswa pada masa pandemic covid-19 di SDN 1 Kilang, Kabupaten Lombok Timur.
\end{abstract}

Kata Kucin : Ramah Anak, Motivasi Belajar, Covid-19.

\section{PENDAHULUAN}

Pandemi Covid-19 memberikan dampak pada banyak pihak, kondisi ini sudah merambah pada dunia pendidikan, pemerintah pusat sampai pada tingkat daerah memberikan kebijakan untuk meliburkan seluruh lembaga pendidikan. Hal ini dilakukan sebagai upaya pencegahan penularan Covid-19. Diharapkan dengan seluruh lembaga pendidikan tidak melaksanakan aktivitas seperti biasanya. Menteri Pendidikan dan Kebudayaan Republik Indonesia mengeluarkan Surat Edaran Nomor 4 Tahun 2020 Tentang Pelaksanaan Kebijakan Pendidikan Dalam Masa Daruat Penyebaran Coronavirus Disease (Covid-19) yaitu bahwa proses pembelajaran dilaksanakan dari rumah.

Pada pembelajaran dalam jaringan (daring), peserta didik dapat menjadi kurang aktif dalam menyampaikan aspirasi dan pemikirannya, sehingga dapat mengakibatkan pembelajaran yang menjenuhkan. Seorang siswa yang mengalami kejenuhan dalam belajar akan memperoleh ketidakmajuan dalam hasil belajar. Oleh karena itu, diperlukan pendorong untuk menggerakkan siswa agar semangat belajar, sehingga dapat memiliki prestasi belajar. Oleh karena itu, motivasi belajar sangat penting untuk dimiliki oleh setiap siswa, baik motivasi intrinsik maupun ekstrinsik. Untuk meningkatkan motivasi belajar siswa pada masa pandemi Covid-19 ini diperlukan pembelajaran yang ramah bagi anak. Pembelajaran yang menyenangkan, nyaman, aman dan realistis bagi anak.

Menurut Rini (Munawarah : 2009) di sekolah perlu dikembangkan pembelajaran yang humanistic yaitu model pembelajaran yang menyadari bahwa belajar bukan merupakan konsekuensi yang otomatis namun membutuhkan keterlibatan mental dan mengubah suasana belajar menjadi lebih menyenangkan dengan memadukan potensi fisik dan psikis siswa. Tidak hanya di sekolah, di lingkungan rumah maupun masyarakat pun perlu diciptakan lingkungan yang aman dan nyaman bagi anak.

Berdasarkan uraian di atas maka diambil satu strategi yaitu dengan menerapkan Pendekatan ramah anak dalam meningkatkan aktivitas belajar siswa. Dalam pembelajaran 
daring ramah anak yang diterapkan di SDN 1 Kilang,keramahan yang dilakukan saat pembelajaran daring (melalui media internet, terutama aplikasi Zoom dan WhatsApp teknik berkomunikasi dengan anak lebih menekankan pada penggunaan bahasa yang santun, ramah dan menyentuh hati siswa. Contoh penerapan kata yang santun melalui melalui aplikasi Zoom "Hai, Anak-anaku yang aku cintai, ibu senang berjumpa dengan kalian melalui media Zoom ini". Dalam pembelajaran luar jaringan (luring) ramah anak yang diterapkan di SDN 1 Kilang. Melalui Home Visit, ketika berkunjung ke rumah anak, guru senantiasa menerapkan kalimat yang benar-benar menyentuh dan menghibur bagi siswa yaitu dengan menerapkan budaya $5 \mathrm{~S}$ (Senyum, sapa, santun, salam dan sabar. Ketika berjumpa dengan siswa selalu menanyakan kabar dan kondisi kesehatan siswa serta keluarganya, kadang memberikan usapan lembut bagi anak yang masih kecil atau siswa kelas rendah. Selain itu, contoh pembelajaran luring, dengan memberikan pembelajaran puisi di kelas 3. Materi pelajaran puisi juga dikaitkan dengan situasi psikologis siswa pada masa pandemic covid-19 ini.

Dengan diterapkannya upaya ini secara maksimal, diyakini akan bisa meningkatkan motivasi belajar siswa dan kualitas pembelajaran di SDN 1 Kilang. Demikian juga aktifitas belajar siswa bisa dioptimalkan dengan menggunakan pendekatan ramah anak. Dengan demikian, maka peneliti tertarik untuk melakukan penelitian lebih dalam tentang bagaimana "Pendekatan Ramah Anak dalam Meningkatkan Motivasi Belajar Siswa pada masa Pandemi Covid-19 di SDN 1 Kilang, Kabupaten Lombok Timur".

\section{METODE PENELITIAN}

Pendekatan penelitian yang digunakan dalam penelitian ini adalah pendekatan kualitatif. Menurut Bogdan dan Taylor (Eri Barlian, 2016) penelitian kualitatif adalah penelitian yang mengahsilkan data deskriptif kata-kata tertulis atau lisan dari orang-orang dan prilaku yang dapat diamati. Pendekatan kualitatif yang digunakan peneliti berupa penelitian dengan rancangan studi kasus (case study). Penelitian studi kasus merupakan rancangan penelitian dengan cara meneliti suatu permasalahan yang terdiri dari unit tunggal. Unit tunggal ini dapat berarti satu orang, atau kelompok yang terkena suatu masalah.

Tujuan dari dilakukannya Pendekatan kualitatif, yaitu untuk mengetahui bagaimana menggunakan suatu kejadian yang terjadi pada saat yang dialami.Salah satu alasan menggunakan metode kualtitatif yaitu untuk menemukan dan memahami apa yang tersembunyi di balik kejadian yang terkadang merupakan sesuatu yang sulit dimengerti dan dipahami. Dengan demikian, data kualitatif adalah data yang bersifat deskriptif, keterangan, informasi, bersifat kata-kata bukan angka-angka.

Sumber data dalam penelitian ini menggunakan sumber data primer dan data sekunder. Data Primer langsung diterima dari sumber data atau informan. Pada penelitian ini data langsung diperoleh dari Kepala Sekolah, guru kelas 3 dan 5, orang tua siswa dan siswa/siswi kelas 3 dan 5 yang berada di SDN 1 Kilang. Data sekunder diperoleh dari penelitian kepustakaan, data sekunder di peroleh dengan mempelajari dan mengkaji literatur-literaturdan perundang-undangan. Atau data sekunder itu berbentuk dokumen, dokumen yang di peroleh dari pihak sekolah atau data online. Pengumpulan data yang digunakan peneliti ialah pengumpulan data berupa wawancara, observasi dan dokumentasi.

Teknik analisis data dalam penelitian ini mengacu pada langkah-langkah yang dikemukakan oleh Miles dan Huberman (Sugiyono : 2017) yaitu yang digunakan dalam analisis data kualitatif terdiri dari tiga langkah yaitu Reduksi data, penyajian data dan penarikan kesimpulan. Kemudian tahapan penelitian ini berawal dari tahapan persiapan kemudian tahapan pelaksanaan dan tahapan penyusunan. 


\section{HASIL DAN PEMBAHASAN}

1. Bentuk pendekatan ramah anak dalam meningkatkan motivasi belajar siswa pada masa pandemi covid-19 di SDN 1 Kilang

Menurut Permen dikbud No. 103 Tahun 2014, "Pendekatan merupakan cara pandang pendidik yang digunakan untuk menciptakan lingkungan pembelajaran yang memungkinkan terjadinya proses pembelajaran dan tercapainya kompetensi yang ditentukan". Berdasarkan penelitian yang dilakukan oleh Nurul Kamilati (2016). Sedangkan definisi pendekatan sistem ramah anak dari temuan peneliti yang diterapkan di SDN 1 Kilang yaitu pendekatan ramah anak tersebut berupaya melindungi dan mengasihi anak dalam setiap aspek kehidupan dengan penuh kasih sayang. Pengelolaan pendidikan di sekolah perlu berpijak pada pendekatan ramah anak karena anak adalah sosok belia yang membutuhkan kata-kata, sikap maupun tindakan yang dilakukan oleh pendidik untuk mempengaruhi perkembangan anak dikemudian hari.

Dalam proses pembelajaran ramah anak di SDN 1 Kilang diterapkan 2 metode pembelajaran yaitu belajar daring ramah anak dan belajar luring ramah anak. Sesuai dengan namanya belajar ramah anak ini lebih mengedepankan keramahtamahan terhadap anak dengan menerapkan budaya 5S yaitu budaya senyum, sapa, salam, santun dan sabar. Dalam belajar daring ramah anak, keramahan yang dilakukan pada saat pembelajaran ialah melalui media Zoom dan WhatsApp. Disini, teknik berkomunikasi pada anak lebih menekankan pada penggunaan bahasa santun, ramah dan menyentuh. Misalnya pada awal pembukaan belajar, sebagai guru hendaknya memberikan kata atau kalimat yang ramah dan menarik pada anak dan ketika bagian penutup pembelajaran dilakukan dengan salam dan memberikan kalimat motivasi kepada anak, sehingga ketika menutup pembelajaran siswa merasa terhibur dan penuh semangat.

Sedangkan belajar luring ramah anak, keramahan yang dilakukan ialah melalui Home visit atau berkunjung ke rumah siswa. Tentunya pembelajaran luring ramah anak dilakukan dengan intensif dan terprogram, menerapkan loyalitas pujian kepada siswa dan memberikan penghargaan kepada siwa. Dapat dilihat dari hasil wawancara, guru ketika berkunjung ke rumah siswa yang pertama dilakukan guru ialah selalu menanyakan kabar siswa serta kabar dari keluarganya, kondisi kesehatannya dan kadang memberikan usapan lembut bagi siswa yang masih kecil atau siswa kelas rendah. Selanjutnya dalam proses pembelajaran luring ramah anak ini lebih mengutamakan stuktur kebahasaan yang baik dalam mengucapkan kalimat. Seperti penerapan dengan memberikan pembelajaran puisi di kelas 3, tentunya puisi tersebut berkaitan dengan keadaan covid-19 sekarang ini.

Menurut pendapat dan teori yang dikemukakan di atas, bentuk pendekatan ramah anak seharusnya tidak hanya memberikan keramahan ketika berlangsungnya proses pembelajaran luring dan daring saja, akan tetapi sebagai seorang guru harus bisa melakukan keramahan pada setiap waktu. Misalnya diluar jam pembelajaran, setidaknya keramahan tersebut bisa diterapkan dalam aspek yang tidak hanya berkaitan dengan pembelajaran luring dan daring. Selain memberikan kasih sayang kepada anak, pada pendekatan ramah anak ini juga harus bisa menyeimbangkan ketegasan kepada anak, supaya anak tidak merasa manja karena hanya diberikan asupan kasih sayang saja.

Jadi, Setelah menerapkan belajar daring dan luring ramah anak tersebut sekolah bisa memberikan hal positif terhadap prilaku dan keaktifan siswa. Meskipun ada kendala-kendala yang masih belum bisa dituntaskan karena mengingat kondisi covid-19 ini. Namun hal tersebut tidak menjadi ukuran terhadap semangat dan antusias siswa dalam melaksanakanya.

2. Faktor penghambat dan pendukung dalam menerapkan pendekatan ramah anak dalam meningkatkan motivasi belajar siswa pada masa pandemi covid-19 di SDN 1 Kilang.

Hal yang paling utama dan terpenting untuk siswa dalam kegiatan pembelajaran ialah adanya sebuah motivasi. Motivasi merupakan sebuah dorongan untuk dapat melakukan sebuah kegiatan belajar siswa dengan sepenuh hati. Berdasarkan penelitian yang dilakukan 
oleh Umi Sa'adah (2020), Motivasi adalah dorongan yang timbul pada diri seseorang secara sadar atau tidak sadar untuk melakukan suatu tindakan dengan tujuan tertentu (KBBI).

Berdasarkan hasil temuan peneliti di SDN 1 Kilang, kabupaten Lombok Timur faktor pendukung peran motivasi dalam belajar adalah pada masa pandemi saat ini dimanfaatkan guru dan orang tua untuk lebih dekat dengan anak begitu juga sebaliknya. Selain memanfaatkan waktu luang bersama anak faktor pendukung dari terbentuknya pendekatan ramah ini ialah dapat dilihat dari bagaimana kualitas guru dalam proses pembelajaran, kualitas karyawan sekolah, dukungan dari masyarakat dan dana dari sekolah.

Terdapat 2 faktor penghambat untuk timbulnya motivasi diantaranya yaitu faktor internal dan eksternal. Faktor internal ini berasal dari siswa itu sendiri seperti rasa malas, kurangnya kepedulian yang diberikan ketika melakukan proses pembelajaran. Selain faktor dari dalam ada juga faktor dari luar seperti kurang kondusifnya suasana belajar, terlebih pada situasi pandemi covid-19, tidak semua siswa memiliki handpone android, kendala transportasi, kendala pengetatan protocol kesehatan, letak rumah siswa yang tidak beraturan, kondisi kesehatan guru, kondisi ekonomi masyarakat dan sekolah dan kurangnya dana dari sekolah.

Beberapa faktor yang dapat mendukung dan menghambat upaya guru dalam meningkatkan motivasi belajar melalui pendekatan ramah anak seperti yang telah dipaparkan di atas. Untuk itu sebagai seorang pendidik, guru harus bisa menjadi teladan yang baik serta bisa mendukung siswanya untuk semangat belajar mengingat pada situasi pandemi sekarang ini. Meskipun demikian terdapat beberapa hambatan dari sistem tersebut, namun diharapkan hambatan itu tidak menjadi beban dalam meningkatkan motivasi belajar siswa.

\section{PENUTUP}

Bentuk pendekatan ramah anak dalam meningkatkan motivasi belajar siswa pada masa pandemi Covid-19 di SDN 1 Kilang, Kabupaten Lombok Timur. Ada 3 kajian dalam bentuk pendekatan ramah anak di SDN 1 Kilang yaitu gambaran pendekatan ramah anak, pembelajaran daring dan luring ramah anak dan pengaruh terhadap motivasi belajar siswa di SDN 1 Kilang. Faktor penghambat dan pendukung dalam menerapkan pendekatan ramah anak dalam menngkatkan motivasi belajar siswa pada masa pandemi covid-19 di SDN 1 Kilang. Faktor yang dapat menjadi pendukung dari terbentuknya sistem ramah anak ini adalah bagaimana kualitas guru dalam proses pembelajaran, kualitas karyawan sekolah dan dana dari sekolah.

\section{DAFTAR PUSTAKA}

Eri Barlian. MS. 2016. Metodologi Penelitian Kualitatif \& Kuantitatif. Sukabina Press: Padang. ISBN: 978-602-1650-90-5.

Munawarah, Shabahatul. 2009. Pola Pembentukan Karakter Anak Melalui Pendidikan Ramah Anak Dalam Perspektif Pendidikan Agama Islam. Skripsi.

(http://digilib.uinsby.ac.id/28157/. Diakses pada 29 Januari 2021).

Kamilati, Nurul. 2016. Dengan Pendekatan Saintifik Berwawasan Ramah Anak: Studi Kasus pada Pembelajaran Lesson Study. Balai Diklat Keagamaan Semarang.

Sa'adah, Umi. 2020. Peran Orang Tua dalam Peningkatan Motivasi Belajar Matematika Pada Masa Pandemi Covid-19: Studi Kasus. Institut Agama Islam Negeri (IAIN) Salatiga.

Surat Edaran Mendikbud Nomor 4 Tahun 2020 tentang Pelaksanaan Kebijakan Pendidikan dalam Masa Darurat Penyebaran Covid-19. (http://pgdikmen.kemdikbud.go.id/read-news/surat-edaran-mendikbud-nomor-4-tahun2020 Diakses 27 Januari 2021)

Sugiyono. 2017. Metode Penelitian Kuantitatif, Kualitatif dan R\&D. Bandung: Afabeta. 